Original Research Paper

\title{
An addition to the alien flora of Java: the first record of adventive Costus dubius (Costaceae)
}

\author{
Wendy A. Mustaqim ${ }^{1 *}$, Eka Setiawan ${ }^{2}$ \\ ${ }^{1}$ Program Studi Biologi, Fakultas Teknik, Universitas Samudra, Jl. Prof. Syarief Thayeb, Meurandeh, \\ Langsa, Aceh, 24416, Indonesia \\ ${ }^{2}$ Plant Biology Graduate Program, Department of Biology, Faculty of Mathematics and Natural \\ Sciences, IPB University, Dramaga, Bogor, 16680, Jawa Barat, Indonesia
}

\author{
Article History \\ Received : February $21^{\text {th }}, 2021$ \\ Revised : April 02 $2^{\text {th }}, 2021$ \\ Accepted : June $30^{\text {th }}, 2021$ \\ Published : July $05^{\text {th }}, 2021$ \\ *Corresponding Author: \\ Wendy A. Mustaqim, \\ Program Studi Biologi, \\ Fakultas Teknik, Universitas \\ Samudra, Langsa, Aceh, \\ Indonesia; \\ Email: \\ wamustaqim@unsam.ac.id; \\ wendyachmmadm@gmail.com
}

\begin{abstract}
More than 6000 plant species, native and introduced, have been recorded in Java that includes the Costaceae family. In the last few years, several additions of alien Costus species have been published from Java. In 2019, a set of specimens of wild Costus sp. was collected from Institut Pertanian Bogor, Bogor, West Java Indonesia. This species is not similar to any previously recorded wild Costus in Java. Therefore, this research aims to identify the collected specimen and provide a taxonomic account for the species. The morphological description was made from the living plant and the collected herbarium. The description was used to identify the species, supported by field notes and photographs. The result showed that the recently collected specimen belongs to Costus dubius. Before this finding, the plant was only known in cultivation in the Bogor Botanical Garden. Therefore, this finding represents the first record of the adventive population of $C$. dubius in Java and increases the number of wild Costus in Java into seven species. Further researches on Costus in Java are suggested such as the ecological impact due to the presence of several non-native species.
\end{abstract}

Keywords: alien plant; herbs; Java; taxonomy

\section{Introduction}

The publication of the Flora of Java by Backer and Bakhuizen van den Brink (1963; $1965 ; 1968)$ is one of the most monumental works to the flora of Java. More than 6000 species native and introduced have been reported. With the gap of more than a half century ago, many new discoveries either new taxon (Mahyuni et al., 2018) or new records of native (Puspitaningrum et al., 2017) or alien plants (Irsyam \& Mountara, 2018; Irsyam et al., 2019a, 2019b, 2020) have been published.

Costaceae is one of the plant families that can be found in Java. The latest taxonomic account on the Costaceae of Java has been published by Backer \& Bakhuizen van den Brink (1968). Later, no more published accounts are available until the 2000s and only Maas (1979) who provided an updated account for all Malesian species where Javan species are also discussed.

Costus is a genus with perhaps as many as 81 to 95 species (Specht, 2006; Specht and Stevenson 2006) and according to POWO
(2021), there are 100 accepted species. This genus can be found from the tropics to subtropic regions of the world (POWO, 2021; Wu \& Larsen, 2000). In 2013, a nomenclatural changes was made in the genus Costus, where some species was transferred to Hellenia (Govaerts, 2013), but this concept seems not acceptable except in some database like Co's Digital Flora of the Philippines (Pelser et al., 2011-onwards). Many species of Costus have been cultivated as ornamental in Java (Nisyawati and Mustaqim, 2017; Skinner, 2016) and some of them possess medicinal properties like in Costus afer KerGawl (Boison et al., 2019).

After the 2000s, further records of Costus species in Java were provided by Sari et al. (2010), Nisyawati \& Mustaqim (2017), Sari et al. (2010), and Irsyam et al. (2019). Sari et al. (2010) mentioned that $C$. dubius has been cultivated in Bogor Botanic Gardens based on the seed they brought in from The Netherlands. Nisyawati \& Mustaqim (2017) reported the occurrence of Costus lucanusianus J. Braun \& K. Schum., Costus malortieanus H. Wendl., and Costus scaber Ruiz \& Pav. in their local flora account of 
Universitas Indonesia, Depok, West Java. The latest record was made by Irsyam et al. (2019b) on Costus afer Ker Gawl. In this paper, we present a record for Costus dubius (Afz.) K. Schum. in Java based on an adventive population for the first time.

\section{Material and Methods}

Field collecting was conducted in the year of 2019 in IPB University campus area supported by previous botanical explorations by both authors since 2017 (Figure 1). According to our field explorations, only one wild population of the targeted species that has been found in IPB University area. Specimen was collected follwing the standar guideline from Bridson and Forman (1992).

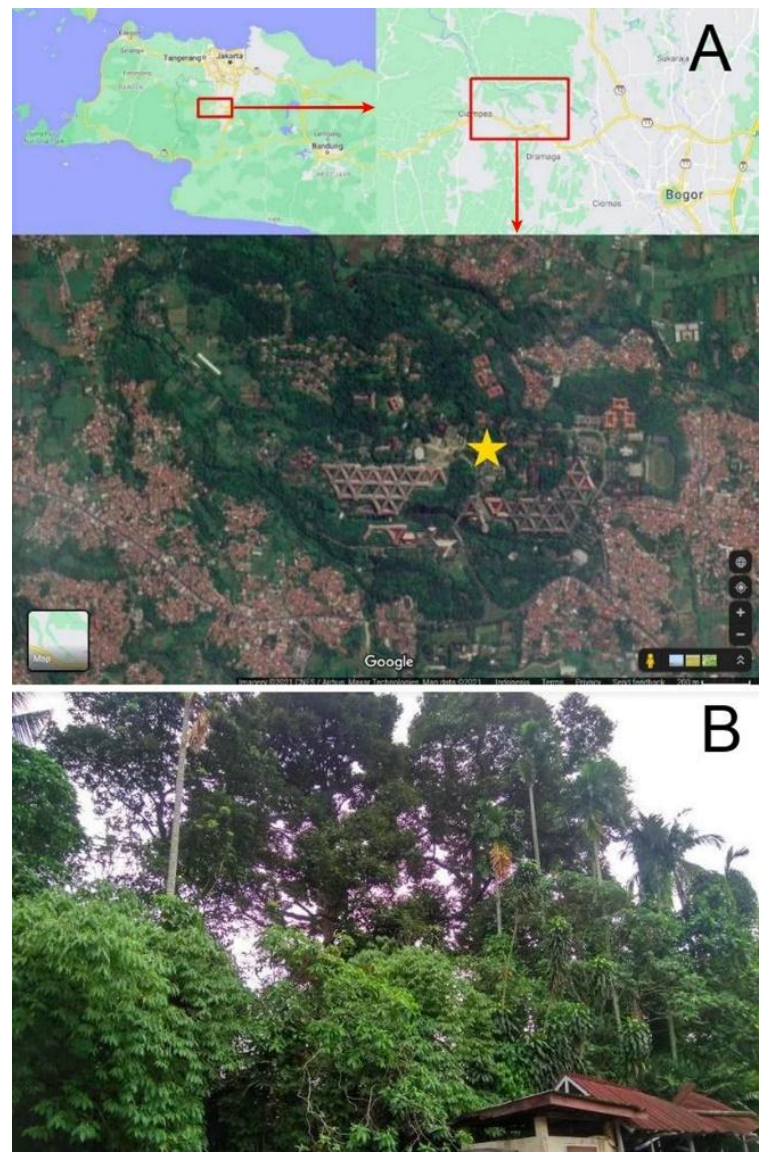

Figure 1. A. Map showing the location of Costus dubius population in IPB University, Bogor, West Java. B. Vegetation where C. dubius was found in IPB University. Photos B by E. Setiawan.

Morphological data of the species were prepared based on dried herbarium materials for the vegetative parts and fresh materials for the generative part including the inflorescence. The identification of the materials was done by using a comparison to descriptions and photographs to many published literatures including Backer \& Bakhuizen van den Brink (1968), Maas (1979), Kramer et al. (2017), Mustaqim \& Nisyawati (2017) and Irsyam et al. (2019).

\section{Results and Discussion}

\section{A. Taxonomic Treatment and Morphological Description}

Costus dubius (Afzel.) K. Schum.: 409 (1904); Maas-van der Kamer et al. Blumea 61: 295 (2016). - Basionym: Zingiber dubium Afzel, Rem. Guin. II: 9 (1813).

Terrestrial herb up to $3 \mathrm{~m}$ tall. Leaves many; ligule chartaceous, nearly truncate to usually 2lobed, 1-16 mm long; petiole 3-10 mm long; sheaths, ligule, and petiole clad with subspreading laxly puberulous hairs, distinct in young plants, mostly up to c. $0.25 \mathrm{~mm}$ and very rarely longer, scabrid with age; lamina shiny above, thinly coriaceous, narrowly elliptic or less frequent obovate, $(8-) 16-32 \times(3.6-) 5-10 \mathrm{~cm}$, upper side minutely puberulous similar to sheaths, lower side glabrous, except the two length side of the midrib, margin often with a row of hairs $<1 \mathrm{~mm}$ long especially in the upper portion, base cuneate, truncate at the very base, apex acuminate, acumen short in smaller individual, and up to $3 \mathrm{~cm}$ long in the larger leaves. Inflorescence many-flowered, vary from globose to ovoid or ellipsoid or subcylindric and tapering to apex, $5.5-13 \times 4.75-7 \mathrm{~cm}$, borne from the separate leafless shoot up to $40 \mathrm{~cm}$ long, one flower bloom at a time. Bracts hairy on the upper dorsal, otherwise glabrous, bracteoles, calyx hairy at the base near the transition with the ovary, corolla glabrous, stamens and style glabrous, ovary with hairs at some parts of the apex. Flowers 1 per bract; bracts green with light margins, margins becoming brownish in the later stage coriaceous, bulging, sterile bracts broadly subobovate, convex, ca. $3.5 \times 4.35 \mathrm{~cm}$, sometimes bearing leaf-like organs at the apex, fertile bracts becoming narrower to the apex of the inflorescence, lowest one very broadly subobovate, up to $3.55 \times 3.8 \mathrm{~cm}$, smaller upward, appendages absent; bracteole falcately boatshaped, ca. $21.5 \mathrm{~mm}$ long, apex bilobed; calyx subinfundibuliform, ca. $17 \mathrm{~mm}$ long including the $3 \mathrm{~mm}$ long, broadly ovate-triangulate lobes, 
callus very inconspicuous; corolla white $45 \mathrm{~mm}$ long, glabrous, tube $13 \mathrm{~mm}$ long, dorsal lobes elliptic, $3.5 \times 1.45 \mathrm{~mm}$, lateral lobes smaller and narrower than the dorsal ones, lobes narrowly subobovate-elliptic, $3 \times 0.95 \mathrm{~cm}$ long; labellum white, inner side with central yellow nectar guide, funnel-shaped, subcampanulate, broadly obovate when spread out, ca. $3.7 \times 3.6 \mathrm{~cm}$, margin crenate in the $1 / 3$ apex; stamen white, very slightly creamy, elliptic, $2.8 \times 1.2 \mathrm{~cm}$, anther $7.5 \times 4.5 \mathrm{~mm}$ long. Ovary white, obovoid, $6 \times 5$ $\mathrm{mm}$, style filiform, $3.45 \mathrm{~mm}$ long, stigma yellowish, $2.5 \times 2.5 \mathrm{~mm}$. Capsule ellipsoid, 12.5 $\times 1 \mathrm{~cm}$. Seeds black, $2.5 \times 2 \mathrm{~mm}$ including the fleshy white-transparent aril (Figure 2 and 3 ).

Specimens examined: INDONESIA. West Java, Bogor, Dramaga, Institut Pertanian Bogor, near SEA FAST, under cultivated durian tree, 3 Feb 2019, Mustaqim \& Setiawan 2303 (FIPIA!).

\section{B. Distribution and Ecology}

This species is native to tropical Africa (Maas-van der Kamer et al., 2016). The previous record in Malesia was made by Maas (1979) from a cultivated plant in Singapore Botanic Gardens and Sari et al. (2010) from plants cultivated in Bogor Botanic Gardens. The adventive population in Java so far known only from the Western part of the island, but maybe also already become adventive elsewhere. The population was found on an abandoned land within a campus area. The plants have already become locally abundant in more or less shaded and humid situations. Flowering seems throughout the year.

C. Important Characters, Notes, and Key Identification for Javan Costus Species

In Java, this species can be recognized solely by the inflorescence that is borne on a separate leafless stem. The plants are strongly assumed to have become naturalized or maybe to a lesser extent, relict of cultivation. Compared to the description in Maas-van der Kamer et al. (2016), we did not find terminal inflorescences and two flowers per bracts in Javan materials. Besides that, we also found that the plants are clad with the minute and subspreading hairs that detached with age and becoming subglabrous. The upper dorsal sides of the bracts are also clad with some hairs. Such difference may be caused by the facts that Maas-van der Kamer et al. (2016) mostly describe the species based on dried materials, which we observed that indumentum is hardly recognized and only appears as powderlike materials. To facilitate the identification of Javan species of Costus, a key is presented below (partly adopted from Maas (1979) and Proctor (2005)):

1a. Leaves villose above C. malortieanus

1b. Leaves glabrous or sparsely hairy but not villous beneath 2

2a. Spikes borne on separate leafless shoots .... C. dubius

2b. Spikes terminal on leafy shoots . 3

3a. Spikes bracts red or orange red ....... C. scaber $3 \mathrm{~b}$. Spikes bract green or sometimes flushed with reddish 4

4a. Bracteoles always or mostly two, rarely 1, per bract 5

4b. Bracteoles one per bract 6

5a. Ring of hairs on the nodes complete; bracts green C. lucanusianus

5b. Ring of hairs on the nodes incomplete; bracts reddish C. afer

6a. Bracts herbaceous, bracteoles tubular C. cuspidatus

6b. Bracts coriaceous to chartaceous, bracteoles boat-shaped C. laevis

\section{Conclusion}

With the addition of $C$. dubius as an adventive or possibly also capable of become naturalized or even invasive in Java, the number of species for Costus in Java is now increased to seven. Further research in the taxonomy of genus Costus or Costaceae family, distribution and studies on some other aspects, such as the ecological impact of the adventive or naturalized species, are encouraged. 


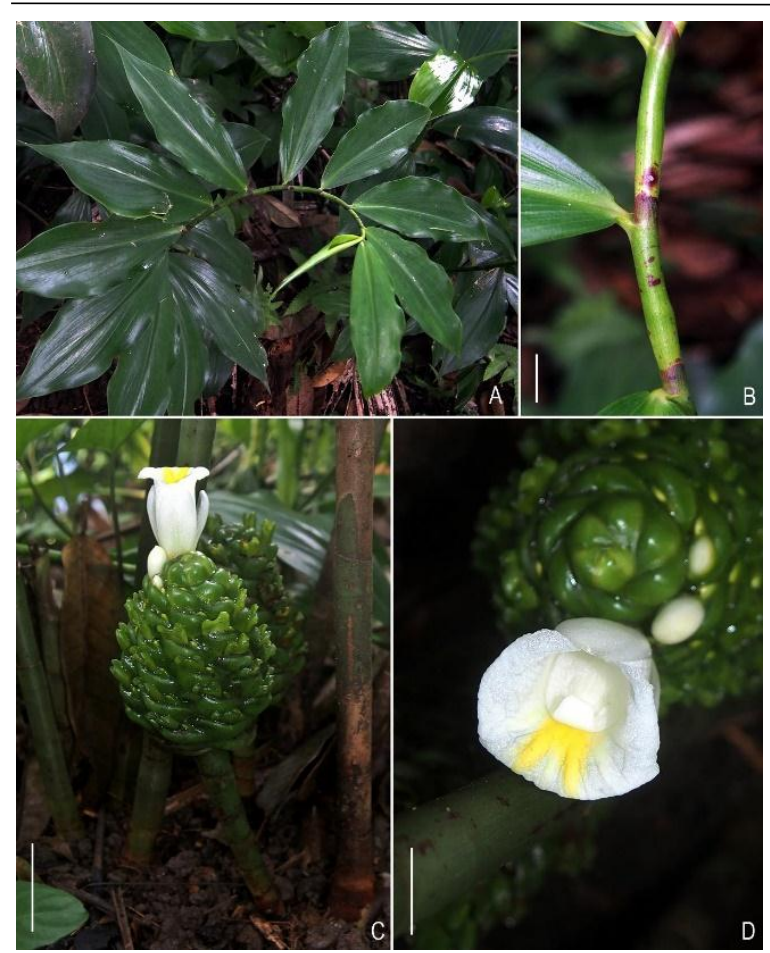

Figure 2. Costus dubius (Afzel.) K.Schum.: A, leafy shoot; $\mathrm{B}$, close up of stem $($ scale $=1 \mathrm{~cm})$; $\mathrm{C}$, inflorescence $($ scale $=$ $5 \mathrm{~cm}$ ); D, flower $($ scale $=2 \mathrm{~cm})$. All from Mustaqim \& Setiawan 2303. Photos by W.A. Mustaqim.

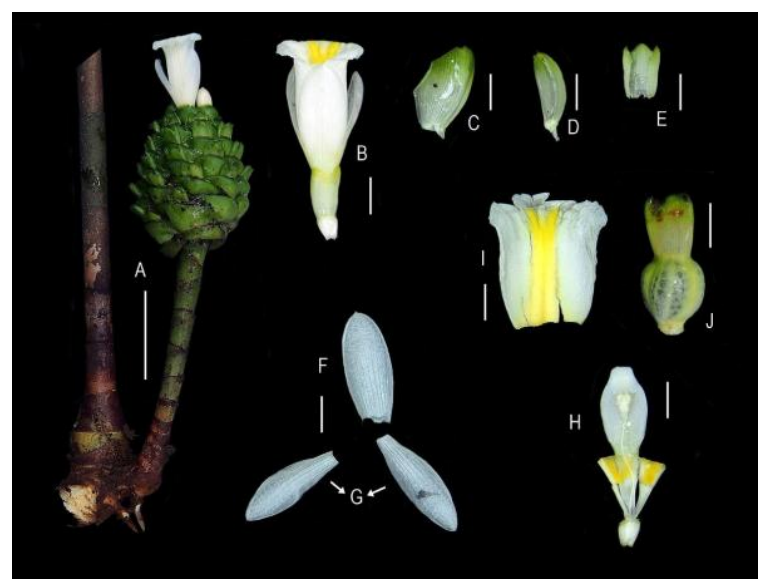

Figure 3. Costus dubius (Afzel.) K.Schum.: A, inflorescence from a separate leafless shoot $($ scale $=5 \mathrm{~cm})$; $\mathrm{B}$, flower $($ scale $=1 \mathrm{~cm}) ; \mathrm{C}$, bract $($ scale $=1 \mathrm{~cm}) ; \mathrm{D}$, bracteole $($ scale $=1 \mathrm{~cm}) ; \mathrm{E}$, calyx $($ scale $=1 \mathrm{~cm}) ; \mathrm{F}$, dorsal petal $($ scale $=1 \mathrm{~cm}) ; \mathrm{G}$, lateral petals $($ scale $=1 \mathrm{~cm}) ; \mathrm{H}$, floral part with perianth and labellum removed $($ scale $=1 \mathrm{~cm}) ; \mathrm{I}$, labellum (scale $=1 \mathrm{~cm})$; J, capsule crowned by persistent calyx. All from Mustaqim \& Setiawan 2303. Photos by W.A. Mustaqim.

\section{Acknowledgements}

The author thanked Laboratory of Ecology and Natural Resources, Department of Biology, IPB University for providing access during the morphological examination of the species. We also deeply indepted to Arifin S.D. Irsyam for discussion regarding the identification Costus species in Java.

\section{References}

APG (Angiosperm Phylogeny Group) IV. (2016). An update of the Angiosperm Phylogeny Group classification for the orders and families of flowering plants, APG IV. Botanical Journal of the Linnean Society 181: 1-20. doi: 10.1111/boj.12385

Backer, C.A. \& Bakhuizen van den Brink, R.C. Jr. (1968). Flora of Java, vol. 3. NVP Nordhoff, Groningen. ISBN: 9789028608849, pp: 761.

Boison, D., Adinortey, C.A., Babanyinah, G.K., Quasie, O., Agbeko, R., Wiabo-Asabil, G.K. \& Adinortey, M.B. (2019). Costus afer: a systematic review of evidencebased data in supports its medicinal relevance. Scientifica 2019: art. 3732687, 10 https://doi.org/10.1155/2019/3732687

Bridson, D. \& Forman, L. (1992). The Herbarium hanbook. Kew: Royal Botanic Gardens.

Govaerts, R. (2013). Hellenia Retz., the correct name for Cheilocostus C.D.Specht (Costaceae). Phytotaxa 151: 63-64.

Irsyam, A.S.D. \& Mountara, A. (2018). Plectranthus monostachyus (P. Beauv.) B.J. Pollard (Lamiaceae) di Jawa. Floribunda 6(1): 32-33. https://doi.org/10.32556/floribunda.v6i1. 2018.223

Irsyam, A.S.D., Hariri, M.R., Al Anshori, Z. \& Irawan, A. (2019a). Rekaman baru Euphorbia graminea Jacq. dan E. hyssopifolia L. (Euphorbiaceae) di Pulau Jawa. Biotika 17(1): 10-18. doi: https://doi.org/10.24198/bjib.v17i1.21902

Irsyam, A.S.D., Irwanto, R.R. \& Hariri, M.R. (2019b). Catatan keberadaan Costus afer Ker Gawl (Costaceae) di Pulau Jawa. $\begin{array}{llll}\text { Floribunda } & 6 & \text { (2): } & 64-71 .\end{array}$ https://doi.org/10.32556/floribunda.v6i2.2 019.252 
Irsyam, A.S.D., Hariri, M.R., Irwanto, R.R. \& Mustaqim, W.A. (2020). A note on the genus Evolvulus (Convolvulaceae) in Java. Jurnal Biodjati 5(1): 90-98.

Maas, P.J.M. (1979). Notes on Asiatic and Australian Costoideae (Zingiberaceae). Blumea 25(2): 543-549. https://repository.naturalis.nl/pub/525131

Maas-van der Kamer, H., Maas, P.J.M., Wieringa, J.J. \& Specht, C.D. (2016). Monograph of African Costaceae. Blumea 61: 280-318. https://doi.org/10.3767/000651916X 694445

Mahyuni, R., Chikmawati, T., Ariyanti, N.S. \& Wong, K.M. (2018). The Psydrax dicoccos complex (Rubiaceae) in Malesia, with three new species. Floribunda 5(8): 322-331.

https://doi.org/10.32556/floribunda.v5i8.2 018.200

Nisyawati, \& Mustaqim, W.A. (2017). A Guide to the Urban Plants of Universitas Indonesia: Spermatophytes. UI Press, Jakarta. ISBN: 9789794567050, pp: 864.

Pelser, P.B., Barcelona, J.F. \& Nickrent, D.L. (eds.). (2011-onwards). Co's Digital Flora of the Philippines. www.philippineplants.org. Accessed 6 Apr 2021.

POWO. (2021). Plants of the World Online. http://www.plantsoftheworldonline.org. Accessed 6 Apr 2021.
Proctor, G.R. Costaceae. (2005). In: AcevedoRodríguez, P. \& Strong, M.T., (Eds.), Monocotyledons and Gymnosperms of Puerto Rico and the Virgin Islands. National Museum of Natural History, Washington, pp: 186-191. ISSN: 00971618

Puspitaningrum, D., Mustaqim, W.A. \& Ardiyani, M. (2017). A new record of Etlingera pauciflora (Zingiberaceae) in Java, Indonesia. Reinwardtia 16: 1-4. doi: 10.14203/reinwardtia.v16i1.2825

Sari, R., Ruspandi \& Ariati, S.R. (2010). An Alphabetical List of Plant Species Cultivated in the Bogor Botanic Gardens. LIPI Press, Jakarta. ISBN: 9789797994945, pp: 320.

Skinner, D. (2016). Ornamental Costus. Campinas-sp. 22(3): 307-317.

Specht, C.D. (2006). Systematics and evolution of the tropical monocot Family Costaceae (Zingiberales): A multiple dataset approach. Systematic Botany 31(1): 89106. Doi: $10.1600 / 036364406775971840$

Specht, C.D. \& Stevenson, D.Wm. (2006). A new phylogeny-based generic classification of Costaceae (Zingiberales). Taxon 55(1): 153-163. doi: $10.2307 / 25065537$

Wu, D. \& Larsen, K. (2000). Costaceae. Flora of China 24: 320-321. 